\title{
Selection strategy for Yield Improvement in F3 Generation of Greengram (Vigna radiata (L.) Wilczek)
}

\author{
B. Lokesh" and G. Roopa Lavanya \\ Department of Genetics and Plant Breeding, Naini Agricultural Institute \\ Sam Higginbottom University of Agriculture, Technology and Sciences \\ Prayagraj-211007, India \\ *Corresponding author
}

Keywords

Greengram, Genetic variability, Heritability,

Character

association, Path analysis.

Article Info

Accepted:

24 August 2019

Available Online:

10 September 2019

\section{A B S T R A C T}

The present investigation was prevailed to examine the 31 greengram genotypes along with one check (Samrat). Maximum genotypic coefficient of variation and phenotypic coefficient of variation were recorded for number of primary branches per plant, seed index, number of clusters per plant and seed yield per plant. High genetic advance was recorded for harvest index, plant height. High heritability coupled with high genetic advance as percent of mean was recorded for number of primary branches per plant and Seed yield per plant exhibited positive significant association with plant height, number of clusters per plant, number pods per plant and harvest index. Path analysis at phenotypic level indicated that days to 50\% flowering, days to maturity, number of pods per plant, number of seeds per pod and harvest index showed maximum positive direct effect on seed yield per plant, which can be used on selection indices for greengram yield improvement.

\section{Introduction}

Greengram (Vigna radiata (L). Wilczek) popularly known as mungbean is the third important legume after chickpea and pigeon pea. It is a self-pollinating, short duration legume that belongs to family Fabaceae with a chromosome number of $2 n=22$. It is mainly grown for its seeds which are used as whole or splits (dhal). The major constraints of greengram production are cultivation under low rainfall condition, low fertile lands, frequent dry spells, poor availability of quality seeds, lack of improved varieties and narrow genetic base. There is an urgent need to enhance the genetic potential of green gram for yield. It is third most important pulse crop of India .It is grown mainly in Madhya 
Pradesh, Maharashtra, Uttar Pradesh, Andhra Pradesh, Karnataka and Rajasthan. Recently domestic consumption of greengram has increased because of the rising popularity in Indian ethnic foods and perceived health benefits (Datta et al., 2012).

The protein is comparatively rich in lysine, an amino acid that is deficient in cereal grains. Greengram seeds are rich in minerals like calcium, iron, magnesium, phosphorus and potassium and vitamins like ascorbic acid, thiamine, riboflavin, niacin, pantothenic acid and vitamin A (Tang et al., 2014).

40 grams of pulses is the recommended daily intake for a balanced diet of an average sedentary man. On the production front, although India ranks first globally in terms of area and production of pulses, it is not yet selfsufficient and remains a net importer of pulses. Among all pulses greengram have high proportion of protein $(24 \mathrm{gm} / 100 \mathrm{gm})$. So research is necessary to release the high yielding variety of greengram to meet the requirement.

\section{Materials and Methods}

The present investigation was carried out at the Field Experimentation Centre, Department of Genetics and Plant Breeding, Sam Higginbottom University of Agriculture, Technology and Sciences, Prayagraj, U.P. during kharif, 2018. All types of facilities necessary for cultivation of successful crop including field preparation, inputs and irrigation facilities were provided In the present investigation, $31 \quad(30+1$ check) greengram (Vigna radiata (L.) Wilczek) genotypes were grown. The experiment was conducted in Randomized Block Design with three replications. The gross area of experiment was $179.55 \mathrm{~m}^{2}$ and cash plot size was $1 \times 1 \mathrm{~m}$ spacing of $30 \mathrm{~cm}$ between rows and $10 \mathrm{~cm}$ between plants. The recommended dose of fertilizer N: P: K @ 20:40:40 kg/ha was applied in the form of Urea, Di-Ammonium Phosphate and Muriate of potash as basal dose at the time of sowing.

\section{Results and Discussion}

Mean data for 12 characters viz., days to $50 \%$ flowering, days to $50 \%$ pod setting, plant height, number of branches per plant, days to maturity, number of clusters per plant, number of pod per plant, pod length, number of seed per pod, biological yield, harvest index, 100 seed weight and seed yield per plant were subjected to analysis of variance for experimental design. The mean sum of squares due to 31 genotypes were highly significant for all the characters studied, suggesting that the experimental materials were genetically divergent from each other. This indicates that there is ample scope for selection of promising lines for the present gene pool for yield and its components. The presence of large amount of variability might be due to diverse source of materials taken as well as environmental influence affecting the phenotypes.

On the basis of mean performance, days to $50 \%$ flowering showed early in Kanpur Mung13-11 X Kanpur Mung-13-18 (39.00), RMG1014 X GANGA-2 genotype had showed early maturity (60.67), number of pods per plant KM-1-02 X KM-13-30 (20.00), number of seeds per pod RMG-1037 X GANGA-1 (11.51), seed yield per plantRMG-1010 X RMG-1071 (6.52 g).

In the present investigation, it estimates of phenotypic coefficient of variation was found higher than their corresponding genotypic coefficient of variation, indicating that the influence of environment on the expression of these characters. However, maximum phenotypic and genotypic coefficient of variation was observed for all the traits in the following genotype (i.e,) number of primary branches per plant (31.83) and number of 
primary branches per plant was observed high for GCV (31.49), followed by seed index for PCV and GCV $(31.08,30.83)$, clusters per plant for GCV and PCV (21.22, 21.00). High heritability was observed for all the traits ranged from pod length (98.4) followed by seed index (98.4) number of primary branches per plant (97.9), and number of clusters per plant (97.9). Genetic advance revealed that it was high for harvest index (9.5), followed by plant height (5.8). Genetic advances as percent of mean was exhibited high for number of primary branches per plant (64.168), followed by seed index (63.004). Seed yield per plant exhibited positive significant correlation with number of clusters per plant $\left(0.498^{* *}\right)$, number of pods per plant $\left(0.465^{* *}\right)$, and plant height $(0.382 *)$.
The correlation (Table-2) showed positive non significant association with days to maturity (0.248), number of primary branches per plant (0.135), days to $50 \%$ flowering (0.129). The correlation showed negative non significant association with number of seeds per plant ($0.185)$ and plant length (-0.132). Character association analysis revealed that seed yield per plant exhibited positive significant association at phenotypic level with plant height $(0.382 *)$, number of clusters per plant $\left(0.498^{* *}\right)$, number of pods per plant $\left(0.465^{* *}\right)$ and harvest index $\left(0.361^{*}\right)$ direct selection for these traits could be helpful in the improvement of Greengram breeding.

Table.1 GCV, PCV, Heritability, Genetic Advance, GA \% of Mean for 12 biometrical characters of greengram

\begin{tabular}{|c|c|c|c|c|c|c|}
\hline S.No & Characters & $\begin{array}{l}\text { Genotypic } \\
\text { coefficient } \\
\text { of variation }\end{array}$ & $\begin{array}{l}\text { Phenotypic } \\
\text { coefficient } \\
\text { of variation }\end{array}$ & $\begin{array}{l}\text { Heritability } \\
\text { (\%) } \\
\text { (broad sense) }\end{array}$ & $\begin{array}{l}\text { Genetic } \\
\text { advance }\end{array}$ & $\begin{array}{l}\text { Genetic } \\
\text { advance } \\
\text { as \% of } \\
\text { mean }\end{array}$ \\
\hline 1 & Days to $50 \%$ flowering & 4.51 & 5.01 & 81.0 & 3.5 & 8.356 \\
\hline 2 & Days to maturity & 2.31 & 2.78 & 69.4 & 2.5 & 3.971 \\
\hline 3 & Plant height & 6.99 & 7.58 & 85.0 & 5.8 & 13.265 \\
\hline 4 & $\begin{array}{l}\text { Number of Primary } \\
\text { Branches per Plant }\end{array}$ & 31.49 & 31.83 & 97.9 & 2.1 & 64.168 \\
\hline 5 & $\begin{array}{l}\text { Number of Cluster per } \\
\text { Plant }\end{array}$ & 21.00 & 21.22 & 97.9 & 2.3 & 42.808 \\
\hline 6 & $\begin{array}{l}\text { Number of Pods per } \\
\text { Plant }\end{array}$ & 7.95 & 8.62 & 85.1 & 2.7 & 15.108 \\
\hline 7 & $\begin{array}{l}\text { Number of Seeds per } \\
\text { Plant }\end{array}$ & 9.90 & 10.22 & 93.7 & 2.1 & 19.734 \\
\hline 8 & Pod Length & 15.27 & 15.39 & 98.4 & 2.1 & 31.188 \\
\hline 9 & Seed Index & 30.83 & 31.08 & 98.4 & 2.1 & 63.004 \\
\hline 10 & $\begin{array}{l}\text { Biological Yield per } \\
\text { Plant }\end{array}$ & 16.52 & 17.08 & 93.6 & 4.3 & 32.913 \\
\hline 11 & Seed Yield per Plant & 19.22 & 19.46 & 97.6 & 2.2 & 39.103 \\
\hline 12 & Harvest Index & 12.66 & 13.68 & 85.6 & 9.5 & 24.133 \\
\hline
\end{tabular}


Table.2 Phenotypic correlation coefficient of seed yield with its component characters in greengram

\begin{tabular}{|c|c|c|c|c|c|c|c|c|c|c|c|}
\hline Character & $\begin{array}{l}\text { Days } \\
\text { to } \\
\text { maturity }\end{array}$ & $\begin{array}{l}\text { Plant } \\
\text { height }\end{array}$ & $\begin{array}{l}\text { Number } \\
\text { of } \\
\text { primary } \\
\text { branches } \\
\text { per plant }\end{array}$ & $\begin{array}{l}\text { Number } \\
\text { of } \\
\text { clusters } \\
\text { per plant }\end{array}$ & $\begin{array}{l}\text { Number } \\
\text { of pods } \\
\text { per } \\
\text { plant }\end{array}$ & $\begin{array}{l}\text { Number } \\
\text { of seeds } \\
\text { per } \\
\text { Pod }\end{array}$ & $\begin{array}{l}\text { Pod } \\
\text { length }\end{array}$ & $\begin{array}{l}\text { Seed } \\
\text { index }\end{array}$ & $\begin{array}{l}\text { Biological } \\
\text { yield }\end{array}$ & $\begin{array}{l}\text { Harvest } \\
\text { index }\end{array}$ & $\begin{array}{l}\text { Seed } \\
\text { yield } \\
\text { per } \\
\text { plant }\end{array}$ \\
\hline $\begin{array}{l}\text { Days to } 50 \% \\
\text { flowering }\end{array}$ & $0.679 * *$ & 0.373* & -0.210 & $0.547 * *$ & 0.095 & 0.009 & $0.488 * *$ & 0.064 & 0.257 & -0.426 & 0.129 \\
\hline $\begin{array}{ll}\text { Days } & \text { to } \\
\text { maturity } & \end{array}$ & 1 & 0.341 & -0.171 & 0.438* & 0.059 & 0.166 & 0.458* & -0.063 & 0.340 & $-0.623 * *$ & 0.248 \\
\hline Plant height & & 1 & $-0.455^{*}$ & $0.702 * *$ & -0.024 & $0.465 *$ & 0.322 & -0.225 & $0.430 *$ & $-0.403 *$ & $0.382 *$ \\
\hline $\begin{array}{l}\text { Number } \quad \text { of } \\
\text { primary } \\
\text { branches } \\
\text { plant }\end{array}$ & & & 1 & $-0.588 *$ & -0.028 & $-0.428 *$ & -0.251 & 0.167 & $-0.381 *$ & $0.472 * *$ & 0.135 \\
\hline $\begin{array}{lr}\text { Number } & \text { of } \\
\text { clusters } & \text { per } \\
\text { plant } & \end{array}$ & & & & 1 & 0.115 & 0.359 & $0.433 *$ & 0.033 & $0.698 * *$ & $-0.453 *$ & $0.498 * *$ \\
\hline $\begin{array}{l}\text { Number of } \\
\text { pods per plant }\end{array}$ & & & & & 1 & -0.198 & 0.000 & 0.131 & -0.122 & -0.165 & $0.465 * *$ \\
\hline $\begin{array}{l}\text { Number of } \\
\text { seeds per pod }\end{array}$ & & & & & & 1 & $0.598 * *$ & -0.175 & 0.364 & $-0.505 * *$ & -0.185 \\
\hline Pod length & & & & & & & 1 & 0.248 & 0.242 & $-0.411 *$ & -0.132 \\
\hline Seed index & & & & & & & & 1 & -0.057 & 0.146 & -0.068 \\
\hline Biological yield & & & & & & & & & 1 & $-0.498 * *$ & -0.106 \\
\hline Harvest index & & & & & & & & & & 1 & $0.361 *$ \\
\hline
\end{tabular}


Table.3 Estimation of direct (Diagonal) and indirect effect of yield and its component characters in greengram

\begin{tabular}{|c|c|c|c|c|c|c|c|c|c|c|c|c|}
\hline Characters & $\begin{array}{l}\text { Days to } \\
50 \% \\
\text { flowering }\end{array}$ & $\begin{array}{l}\text { Days to } \\
\text { maturity }\end{array}$ & $\begin{array}{l}\text { Plant } \\
\text { height }\end{array}$ & $\begin{array}{l}\text { Number of } \\
\text { primary } \\
\text { branches } \\
\text { per plant }\end{array}$ & $\begin{array}{l}\text { Number } \\
\text { of } \\
\text { clusters } \\
\text { per plant }\end{array}$ & $\begin{array}{l}\text { Number } \\
\text { of pods } \\
\text { per } \\
\text { plant }\end{array}$ & $\begin{array}{l}\text { Number } \\
\text { of seeds } \\
\text { per pod }\end{array}$ & $\begin{array}{l}\text { Pod } \\
\text { length }\end{array}$ & $\begin{array}{l}\text { Seed } \\
\text { index }\end{array}$ & $\begin{array}{l}\text { Biological } \\
\text { yield }\end{array}$ & $\begin{array}{l}\text { Harvest } \\
\text { index }\end{array}$ & $\begin{array}{l}\text { Seed } \\
\text { yield } \\
\text { per } \\
\text { plant }\end{array}$ \\
\hline $\begin{array}{l}\text { Days to } 50 \% \\
\text { flowering }\end{array}$ & 0.203 & 0.268 & -0.177 & -0.018 & 0.045 & 0.025 & 0.003 & -0.198 & -0.004 & -0.027 & 0.011 & 0.129 \\
\hline $\begin{array}{ll}\text { Days } & \text { to } \\
\text { maturity } & \end{array}$ & 0.138 & 0.394 & -0.163 & -0.014 & 0.036 & 0.015 & 0.047 & -0.186 & 0.004 & -0.035 & 0.015 & 0.248 \\
\hline Plant height & 0.075 & 0.134 & 0.478 & -0.039 & 0.057 & -0.005 & 0.126 & -0.130 & 0.014 & -0.045 & 0.010 & 0.382 \\
\hline $\begin{array}{l}\text { Number of } \\
\text { primary } \\
\text { branches per } \\
\text { plant }\end{array}$ & -0.043 & -0.067 & 0.220 & 0.085 & -0.048 & -0.007 & -0.118 & 0.101 & -0.011 & 0.040 & -0.012 & 0.135 \\
\hline $\begin{array}{l}\text { Number of } \\
\text { clusters per } \\
\text { plant }\end{array}$ & 0.112 & 0.173 & -0.335 & -0.050 & 0.082 & 0.027 & 0.099 & -0.174 & -0.002 & -0.073 & 0.011 & 0.498 \\
\hline $\begin{array}{lr}\text { Number } & \text { of } \\
\text { pods } & \text { per } \\
\text { plant } & \end{array}$ & 0.020 & 0.024 & 0.010 & -0.003 & 0.009 & 0.247 & -0.055 & 0.000 & -0.008 & 0.013 & 0.004 & 0.465 \\
\hline $\begin{array}{l}\text { Number of } \\
\text { seeds per pod }\end{array}$ & 0.002 & 0.067 & -0.220 & -0.037 & 0.030 & -0.049 & 0.274 & -0.243 & 0.012 & -0.038 & 0.012 & -0.185 \\
\hline Pod length & 0.100 & 0.181 & -0.153 & -0.021 & 0.035 & 0.000 & 0.164 & -0.405 & -0.016 & -0.025 & 0.010 & -0.132 \\
\hline Seed index & 0.012 & -0.024 & 0.105 & 0.014 & 0.002 & 0.032 & -0.049 & -0.101 & -0.065 & 0.006 & -0.004 & -0.068 \\
\hline $\begin{array}{l}\text { Biological } \\
\text { yield }\end{array}$ & 0.053 & 0.134 & -0.206 & -0.032 & 0.057 & -0.030 & 0.099 & -0.097 & 0.004 & -0.104 & 0.012 & -0.106 \\
\hline $\begin{array}{l}\text { Harvest } \\
\text { index }\end{array}$ & -0.087 & -0.244 & 0.191 & 0.040 & -0.037 & -0.039 & -0.137 & 0.166 & -0.010 & 0.052 & 0.425 & 0.361 \\
\hline
\end{tabular}


Path analysis (Table-3) at phenotypic level indicates the days to $50 \%$ flowering(0.203), days to maturity (0.394), plant height (0.478), number of primary branches per plant (0.085), number of clusters per plant (0.082), number of pods per plant (0.247), number of seeds per pod (0.274), harvest index $(0.425)$ had maximum positive direct effect on seed yield per plant. On the basis of results of the experiment it can be conducted that the genotypes have observed $50 \%$ flowering which showed early in KM-1311 X KM-13-18 (39.00), RMG-1014 X GANGA-2 genotype had showed early maturity (60.67), number of pods per plant KM-13-02 X KM-13-30 (20.00), number of seeds per pod RMG-1037 X GANGA-1 (11.51), seed yield per plant RMG-1010 X RMG-1071 (6.52 g).

\section{References}

Anonymous (2011). Agriculture Statistics at a glance.Directorate of Economics and Statistics, New Delhi.

Ahmad, N., Lavanya, G.R. and Kole, C. (2007).Estimation of genetic divergence in greengram (Vigna radiata (L.) Wilczek) Journal of Maharashtra Agricultural universities, 32(3): 430-432.

Ahmad, H. B. (2014). Genetic variability for yield contributing traits in mungbean (Vigna radiata (L.) Wilczek). Journal of Global Innovative Agricultural Social Sciences, 2(2): 52-54.

Ammavasai, S., Phogat, D.S. and Solanki, I.S. (2005). Genetics of some quantitative traits in mungbean. Indian Journal of Pulses Research, 18(2): 127-130.

Azam, M.G., Hossain, M.A., Alam, M.S., Rahman, K.S. and Hossaian, M. (2018). Genetic variability, heritability and correlation path analysis in mungbean (Vigna radiata (L) Wilczek). Bangladesh Journal of
Agriculture Research, 43(3): 407-416.

Bakshi, A., Bala, S. and Dostisder, K. G. (2006). Character association for seed yield components in black gram (Vigna mungo (L.) Hepper). Environment and Ecology, 24(3): 943945.

Burton, G.W. and De Vane, E.M.(1953). Estimating heritability in tall fesses from replicated cloned material. Journal of Agronomy, 45(3):474-481.

Bisht, I. S., Bhat, K.V., Lakhanpaul, S., Latha, M., Jayan, P. K., Biswas B. K. and Singh, A. K. (2005).Diversity and genetic resources of wild vigna species in India. Genetic Resource, 52: 53-68.

Bharti, B., Singh and S. Kumar, P. (2014). Study on correlation and path analysis in blackgram (Vigna mungo (L.) Hepper).Legume Research, 18(2):2528.

Das, A.M., Biswas and Dastidar, K. K. G. (2010). Genetic divergence in greengram (Vigna radiata (L.) Wilczek).Scialert.net/abstract/doi: Journal(1): 26-30.

Denton, O. A., and Nwangburuka, C. C. (2011). Heritability, genetic advance and character association in six related characters of Solanum anguivi. Asian Journal of Agricultural Research, 5: 201-207.

Dhuppe, M. V., Madrap, I. A., Chandankar, G. D. and More, S. S. (2005). Correlation and path analysis in mungbean. Journal of Soil and Crops, 15(1): 8489.

Degefa, I., Petros, Y. and Andargie, M. (2014). Genetic variability, heritability and genetic advance in mungbean (Vigna radiata (L.) Wilczek) accessions. Plant Science Today, 1(2): 94-98.

Falconer, D.S. (1981). Introduction to Quantitative genetics, $3^{\text {rd }}$ edition. Longman, New York. Pp340. 
Fisher, R.A. (1936). Statistical tables for biological, agricultural and mendelian inheriatance. France Royal Society of Edinburgh, 52: 399- 433.

Gadakh, S. S., Dethe, A. M. and Kathale, M. N. (2013). Genetic variability, correlations and path analysis studies on yield and its components in mungbean (Vigna radiata (L.) Wilczek) Bioinfolet, 10(2a):441-447.

Haritha, S. and Sekhar, M. R. (2002). Correlation and path analysis in mungbean. Legume Research, 25(3): 180-183.

IrannaNagaral and Kajjidoni, S. T. (2005). Association analysis of advance breeding lines of greengram. Karnataka Journal of Agricultural Sciences, 18(4): 925-930.

Jyothsnanand, M. and Anuradha, C.H. (2013). Genetic variability, correlation and path analysis for yield and yield components in mungbean (Vigna radiata (L.) Wilczek). Journal of Research ANGRAU, 41(3):31-39.

Johnson, H.W., Robinson, H.E., and Comstock, R.E., (1955). Estimates of genetic and environmental variability in soybean. Agronomy Journal, 47: 314-318.

Kute, N.S. and Deshmukh, R.B. (2003). Genetic analysis in mungbean (Vigna radiata (L.). Legume Research, 25(4):258-261.

Khajudparn, $\mathrm{P}$ and Tantasawat, P. (2011).Relationships and variability of agronomic and physiological characters in mungbean. African Journal of Biotechnology, 10(49): 9992-10000.

Kamleshwar, K., Yogendra, P., Mishra, B., Pandey, S. and Kumar, R. (2012). Study on genetic variability, correlation and path analysis with grain yield and yield attributing traits in green gram [vigna radiata (L.)
Wilczek].The Bioscan, 8(4): 15511555.

Kousar, M., Abrahim, G., Jan, A. and Singh, K.A. (2007), Genetic variability and correlation studies on yield and its components in mungbean (Vigna radiata (L). Wilczek).Journal of Agronomy, 6(1):216-218.

Khan, N.H., Islam, M.A., Begum, S., Begum, M. and Shamsuzzaman, S.M. (2008). Genetic variation for yield in mungbean. [Vigna radiata (L.) Wilczek]. International Journal of Sustainable Agricultural Technology, 4(5): 40-43.

Kumar, S.S., Sudharshanam, A., Vinodkumar, S. and Narasimhareddy, V.(1995), Correlation and path coefficient analysis in greengram (Vigna radiata). Madras Agricultural Journal, 82(2): 160- 162.

Keatinge, J., Easdown, W., Yang, R., Chadha, M. and Shanmugasundaram, S. (2011). Overcoming chronic malnutrition in a future warming world: the key importance of mungbean and vegetable soybean. Euphytica, 180: 129-141.

Lavanya, G.R. (2006). Evaluation of mungbean germplasm for genetic variability. Indian Journal of Plant Genetic Resources, 19(1): 104-106.

Mishra, R.C. and Sahu, B.C. (1985). Genetic parameters, correlations and coefficient analysis in greengram (Vigna radiata (L.) Wilczek). The Andhra Agricultural Journal, 32(2): 87-91.

Mallikarjuna, R.C.H., Koteswara Rao, Y and Reddy, M.V. (2006). Evaluation of mungbean germplasm for yield and yield components. Legume research, 29(1): 13-15.

Muralidhara, Shanthala, J., Savithramma, D. L., Gangappa, E. and Shankar, A. G. (2016). A Comparative Genetic Analysis of Seed Yield and its Attributes in two Crosses of 
Greengram (Vigna radiata (L.) Wilczek). Mysore Journal of Agriculture Sciences, 50(3): 541-554.

Murty, B.R. and Arunachalam, V. (1966).The nature of genetic divergence in relation to breeding system in crop plants. Indian Journal of Genetics and plant Breeding.26: 188-98.

Makeen, K., Abrahim, G., Jan, A. and Singh, A. K. (2007).Genetic variability and correlations studies on yield and its components in mungbean (Vigna radiata (L.) Wilczek). Journal of Agronomy, 6: 216-218.

Malik, M.F.A., Qureshi, A.S., Ashraf, M. and Ghafoor, A. (2006). Genetic variability of the main yield related characters in soybean. International Journal of Agricultural Biology, 8(6): 815.

Nandi, A., Tripatly, P. and Hencha, D. (1999). Character association, path analysis and selection indices in brown seeded pole French bean (Phaseolus vulgaris).Egyptian. Journal of Horticulture, 26: 59-66.

Parameswarappa, S. G. (2005). Genetic variability, character association and path coefficient analysis in greengram. Karnataka Journal of Agricultural Science, 18(4): 1090-1092.

Panse, V.G. (1957). Genetics of quantitative characters in selection plant breeding. Indian Journal of Genetics, 17:318328.

Panigrahi, K. K., Mohanty, A. and Baisakh, B. (2014). Genetic divergence, variability and character association in landraces of blackgram (Vigna mungo (L.) Hepper) from Odisha, Journal on Crop and Weed, 10(2): 155-165.

Patil, V. S., Deshmukh, R. B. and Patil, J.V. (1996). Genetic analysis of quantitative characters in mungbean, Indian Journal of Pulses Research, 9(20): 132-136.

Prakash, B.G. and Khanure, S.K.
(2000).Genetic parameters, correlation and path co-efficient analysis in horsegram (Macrotylomauniflorum Lam.).Karnataka Journal of Agricultural Sciences, 13(2):312-314.

Rahim, M. A., Mia, A. A., Mahmud, F., Zeba, N. and Afrin, K.S. (2010). Genetic variability, character association and genetic divergence in mungbean (Vigna radiata (L.) Wilczek). Plant Omics Journal, 3(1): 1-6.

Roy chowdhury, R., Datta, S., Gupta, P. and Tah, J. (2012). Analysis of Genetic Parameters on Mutant Populations of Mungbean (Vigna radiata (L.) Wilczek) after Ethyl Methane Sulphonate Treatment. Notulae Scientia Biological, 4(1): 137-143.

Reni, Y.P., Rao Y.K., Satish, Y. and Babu, J.S. (2013). Estimates of genetic parameters and path analysis in blackgram (Vigna mungo (L.) Hepper). International Journal of Plant, Animal and Environmental Sciences, 3(4): 231-234.

Rao, C.M., Rao, Y.K. and Mohan, R. (2006). Genetic variability and path analysis. Legume Research, 29(3):216-218.

Reddy, V. L. N., ReddiSekhar, M., Reddy, K. R. and Reddy, K. H. (2003).Genetic variability for yield and its components in mungbean (Vigna radiata (L.) Wilczek).Legume Research, 26(4): 300-302.

Rohman Motiar, Md., IqbalHussain, A. S. M., SaykhulArifin, Md., Zerin and Mizra Hasanuzzaman (2003). Genetic variability, correlation and path analysis in mungbean. Asian Journal of Plant Sciences, 2(17, 24): 12091211.

Srivastava, R. L and Singh, G. (2012). Genetic variability, correlation and path analysis in mungbean (Vigna radiata (L.) Wilczek). Indian Journal of Life Sciences, 2(1): 61-65. 
Saleem, M., Hammad, M., Tahir, N., Kabir, R., Javid, M. and Shahzad, K. (2002). Interrelationship and path analysis of yield attributes in chickpea (Cicer arietinum L.). International Journal of Agriculture and Biology, 4: 404-406.

Sabu K. K., Abdullah M. Z., Lim L. S., and Wickneswari, R. (2009). Analysis of heritability and environmental variances in a rice cross. Agronomy Research, 7: 97-102.

Shil, S. and Bandopadhyay, P. K. (2007). Retaining seed vigour and viability of mung bean by dry dressing treatments. Journal of Food Legumes, 20:173-75.

Singh, I.S., Hue, N.T.N. and Gupta, A.K. (1995). Association and cause and effect analysis in some $\mathrm{F}_{2}$ populations of greengram. Legume Research, 18: 137-142.

Samad, S.S. and Lavanya, G.R. (2005). Variability studies for yield parameters in mungbean [Vigna radiata (L.) Wilczek]. Journal of Maharashtra Agriculture University, 30(2): 168-170.

Srivastava, R.L. and Singh, G. (2012).Genetic variability, correlation and path analysis in mungbean (Vigna radiata (L.)Wilczek).Indian Journal of Library Sciences, 2(1): 61-65.

Tejbir, Singh., Sharma, Amitesh. And Alie, F. A. (2009). Impact of environment on heritability and genetic gain for yield and it component traits in mung bean. Legume Research, 32(1): 55-58.

Varma, P. and Garg, D. K. (2003).Estimation of genetic parameters among a set of mungbean (Vigna radiata (L.) Wilczek) genotypes. Annals of Agricultural Research, 24(1): 156-158.

Venkateswarlu, O. (2001). Genetic variability in green gram (Vigna radiata (L.) Wilczek). Legume Research, 24(1): 69-70.

Yaqoob, M. Ahmad Bakhsh., Khan Najeebullah., Ashraf Zahid M. and Lal HussainAkhtar (2010). Studies on heritability and genetic advance in Chickpea (Cicer arietinum L.). Science Technology \& Development, 29(3): 1013.

\section{How to cite this article:}

Lokesh, B. and Roopa Lavanya, G. 2019. Selection strategy for Yield Improvement in F3 Generation of Greengram (Vigna radiata (L.) Wilczek). Int.J.Curr.Microbiol.App.Sci. 8(09): 2697-2705. doi: https://doi.org/10.20546/ijcmas.2019.809.311 